Urszula Nowicka

Wydział Prawa Kanonicznego UKSW

\title{
Małżeństwa mieszane wedle koncepcji Kościoła katolickiego, Kościoła prawosławnego oraz Kościoła ewangelicko-augsburskiego w Polsce
}

10 maja 2011 r. opublikowany został projekt dokumentu dotyczącego małżeństwa chrześcijańskiego osób o różnej przynależności wyznaniowej, o którym napisano, że jest „owocem wieloletniej współpracy Komisji Teologicznej Polskiej Rady Ekumenicznej i Komisji ds. Dialogu między Polską Radą Ekumeniczną a Konferencją Episkopatu Polski Kościoła Rzymskokatolickiego"1. Po czterech latach od tego czasu, projekt ów znajduje się nadal w fazie konsultacji z Kościołami. Oznacza to z jednej strony jakąś wolę współpracy, z drugiej jednak wskazuje, jak trudna jest problematyka małżeństw, w których małżonkom brakuje jedności w kwestii wyznawanej wiary. Każdy z nich ma bowiem swoje zobowiązania i każdy powinien dążyć do ich realizacji, również w tym, co dotyczy chrztu i wychowania potomstwa. A jeszcze trudniejsza sytuacja ma miejsce wówczas, kiedy małżeństwo ma być zawarte $\mathrm{z}$ osobą nieochrzczoną, należącą do innej religii niechrześcijańskiej lub bezwyznaniową.

Takie małżeństwa to zawsze wybór pomiędzy ius connubii każdego człowieka a koniecznością obrony wiary przed niebezpieczeństwami,

1 Małżeństwo chrześsijańskie osób o różnej przynależności wyznaniowej. Deklaracja Kościołów w Polsce na początku Trzeciego Tysiąclecia (projekt dokumentu z 10 maja 2011 r.), http://ekumenia.pl/czytelnia/dokumenty-ekumeniczne/malzenstwo-chrzescijanskie-osob-o-roznej-przynaleznosci-wyznaniowej/ (data dostępu: 30 kwietnia 2015 r.) 
jakie mogą z nich wynikać. W poniższym studium zostanie przedstawiona koncepcja tychże małżeństw - w ujęciu szerokim, tzn. zarówno małżeństw mieszanych wyznaniowo, jak i religijnie - z punktu widzenia trzech największych - pod względem liczebności wiernych - Kościołów w Polsce, tzn. Kościoła rzymskokatolickiego, Kościoła prawosławnego oraz Kościoła ewangelicko-augsburskiego.

\section{Małżeństwa mieszane w ujęciu Kościoła katolickiego}

Długa i trudna ewolucja prawnego ujęcia małżeństw mieszanych w Kościele katolickim doprowadziła w ostateczności do ścisłego rozróżnienia pomiędzy małżeństwami zawieranymi z osobami nieochrzczonymi oraz z chrześcijanami należącymi do innych Kościołów i wspólnot kościelnych ${ }^{2}$. Ta pierwsza sytuacja oznacza przeszkodę małżeńską, która jako prawo uniezdalniające, skutkuje nieważnością ewentualnego małżeństwa. Z kolei zawieranie małżeństw z ochrzczonymi akatolikami jest zakazane i wymaga uprzedniej zgody ordynariusza miejsca, koniecznej dla godziwego zawarcia małżeństwa.

Kościół, świadom trudności, jakie rodzą się w tego rodzaju małżeństwach, odradza ich zawierania, „gdyż bardzo pragnie, ażeby katolicy mogli osiągnąć w małżeństwie doskonałą harmonię duchową oraz pełną wspólnotę życia"3. Wie jednak także, że w małżeństwach mieszanych weryfikuje się konflikt pomiędzy iuris divini praescripta i prawem homini a natura datum. Owszem, jak pisze Urbano Navarrete, prawo do zawarcia małżeństwa jest prawem a natura datum. Jednak jego wykonywanie nie jest niezależne od porządku moralnego i etycznego, ale jest mu podporządkowane. Dlatego w przypadku konfliktu pomiędzy wykonywaniem prawa

2 Na temat rzeczonej ewolucji por. P. ErDö, I matrimoni misti nella loro evoluzione storica (la disparità di culto), w: AA.Vv., I matrimoni misti, Studi Giuridici XLVII, Città del Vaticano 1998, s. 11-22.

3 Por. Paulus VI, Litterae apostolicae motu proprio datae. Normae de matrimoniis mixtis statuuntur Matrimonia mixta, 31 III 1970, AAS 62 (1970), s. 258; tekst polski w: E. Sztafrowski (opr.), Posoborowe Prawodawstwo Kościelne, t. III, z. 2, Warszawa 1971, s. 7. 
do małżeństwa a wartościami wyższymi, którymi są wiara, życie wieczne, wierność wymaganiom własnego sumienia, przeważa obowiązek obrony tych wartości, nawet za cenę zanegowania realizacji prawa do małżeństwa $\mathrm{z}$ określoną osobą ${ }^{4}$.

$\mathrm{Z}$ powyższego wynika $\mathrm{z}$ jednej strony pewien rygoryzm prawa, $\mathrm{z}$ drugiej natomiast pewne otwarcie. Kościół nie traktuje bowiem swojego stanowiska wobec małżeństw mieszanych w sensie absolutnym. Owszem, przeszkoda różności religii czy zakaz zawarcia małżeństwa mieszanego obowiązuje również wówczas, gdy nie ma bezpośredniego niebezpieczeństwa dla wiary katolika czy przyszłego potomstwa ${ }^{5}$, tym niemniej pod pewnymi warunkami Kościół katolicki zgadza się na takie małżeństwa, poprzez danie możliwości udzielania dyspensy od przeszkody lub zezwolenia ze strony ordynariusza miejsca.

Warunki te określone zostały w Kodeksie Prawa Kanonicznego w kan. $1125 \mathrm{n}$. 1-3, w rozdziale o małżeństwach mieszanych rozumianych w znaczeniu ścisłym (tzn. zawieranych z akatolikami ochrzczonymi). Tym niemniej z mocy kan. $1086 \$ 2 \mathrm{KPK}$, należy aplikować je także w sytuacji, w której będzie chodziło o udzielenie dyspensy od przeszkody różności religii.

W kanonie użyty został ogólny termin „condiciones”, obejmujący konieczne akty wymienione w jego poszczególnych punktach; chodzi mianowicie o „declaro” (n. 1: „pars catholica declaret se [...]”), „promitto” (n. 1: „pars catholica sinceram promissionem praestet [...]”), „certioro” (n. 2: „faciendis altera pars tempestive certior fiat”) oraz „edoceo” (n. 3: „ambae partes edoceantur”). Każdy z nich odnosi się do innego aspektu przedmiotowej kwestii, natomiast wszystkie są konieczne dla możliwości proszenia o łaskę dyspensy lub zezwolenia na zawarcie małżeństwa mieszanego.

Tak więc w pierwszej kolejności strona katolicka powinna oświadczyć, że jest gotowa odsunąć od siebie niebezpieczeństwo utraty

4 Por. U. Navarrete, Matrimonii misti: conflitto fra diritto naturale e teologia, Quaderni di Diritto Ecclesiale 5 (1992), s. 276-277.

5 A. D’Auria, Gli impedimenti matrimoniali, Città del Vaticano 2007, s. 109. 
wiary. Choć takie oświadczenie jest niewątpliwie wymaganiem prawa kościelnego, to jednak już sam obowiązek odsunięcia od siebie tego niebezpieczeństwa ma swoje źródło w prawie Bożym ${ }^{6}$ Stąd też należy podkreślić, że od zobowiązania, o którym mowa, nie ma odstępstw. Jeśli zatem z oświadczenia katolika wynikałoby, że ignoruje je i że nie podejmie żadnych wysiłków zmierzających do pielęgnowania i ochrony swojej wiary, wówczas udzielenie stosownej dyspensy czy zezwolenia nie byłoby możliwe ${ }^{7}$.

Strona katolicka winna następnie „złożyć szczere przyrzeczenie, że uczyni wszystko, co w jej mocy, aby wszystkie dzieci zostały ochrzczone i wychowane w Kościele katolickim”. Nie ma wątpliwości, iż zobowiązanie to pozostaje w ścisłym związku z wyżej omówionym, tym niemniej należy zwrócić tutaj uwagę na zasadnicze różnice, które bynajmniej nie pozostają jedynie kwestią terminologiczną. Obecne „szczere przyrzeczenie” nie ma już charakteru tak radykalnego, jak „oświadczenie”, będące czymś bezwarunkowym. Przyrzeczenie zawiera w sobie ewentualność niewypełnienia zobowiązania ${ }^{8}$, o czym świadczy również dodana w kanonie klauzula „se omnia pro viribus”. W doktrynie przyjmuje się zatem, iż jeśli strona katolicka znalazłaby się w sytuacji przekraczającej granice jej naturalnych możliwości wypełnienia obowiązku ochrzczenia i wychowania dzieci w Kościele katolickim, wówczas, przy założeniu jej szczerej woli, należałoby uznać, iż spełnia warunek, o którym mowa9.

6 Por. G. Dzierżon, Ewolucja doktryny oraz dyscypliny dotyczących przeszkody „różności religii” w kanonicznym porządku prawnym, Warszawa 2008, s. 316; J. CASTAÑo, Il sacramento del matrimonio, Roma 1993, s. 467.

7 Por. G. DzIerżon, Przygotowanie do zawarcia mażłeństwa katolika z protestantem, Ius Matrimoniale 25 (2014), n. 1, s. 46.

8 Por. M. Bucciero, I matrimoni misti. Aspetti storici, canonici e pastorali, Roma 1997, s. 138 .

9 Por. G. Dzierżon, Problem konieczności wypetnienia warunków dotyczacych stron umowy małżeńskiej określonych przez ustawodawstwo Kościoła polskokatolickiego w przypadku zawierania małżeństwa mieszanego przez katolika w Kościele polskokatolickim, Ius Matrimoniale 25 (2014), n. 4, s. 52-53. 
Jeśli zaś chodzi o małżonka akatolickiego, ochrzczonego bądź nie, prawo nie stawia mu żadnych warunków w odniesieniu do powyższej kwestii. Innymi słowy, nie wymaga od strony akatolickiej złożenia żadnych oświadczeń czy przyrzeczeń, a jedynie zobowiązuje do poinformowania jej, w odpowiednim czasie, o zobowiązaniach strony katolickiej, w taki sposób, aby była ich rzeczywiście świadoma. Nie musi ich jednak akceptować, ani zgadzać się z nimi, wystarczy, aby wiedziała, że istnieją i że małżonek katolicki ma obowiązek ich realizacji. W doktrynie podkreśla się, iż norma ta inspirowana jest ideą ekumenizmu oraz szacunkiem wobec osoby ludzkiej i jej wolności religijnej ${ }^{10}$. To prawda; nie trudno jednak dostrzec, jak wiele trudności praktycznych może wynikać z faktu, że do złożenia podobnych zobowiązań może być obligowana również druga strona w małżeństwie mieszanym, w oparciu o prawo, któremu podlega. Wydaje się, że kwestie te domagają się nie tylko szczególnej troski duszpasterskiej, ale także ponownej refleksji prawnej, najlepiej przy czynnym współudziale przedstawicieli różnych Kościołów i wspólnot kościelnych.

Prawodawca katolicki wymaga następnie, aby „obydwie strony były pouczone o celach i istotnych przymiotach małżeństwa, których nie może wykluczyć żadna ze stron". Owo wykluczenie prowadziłoby bowiem do nieważności małżeństwa w oparciu o kan. $1101 \$ 2 \mathrm{KPK}$, niezależnie od tego, która strona odrzuciłaby, pozytywnym aktem woli, dobro małżonków lub dobro potomstwa albo jedność lub nierozerwalność małżeństwa. Wydaje się, iż szczególnego znaczenia nabiera tutaj kwestia nierozerwalności małżeństwa, poprzez dopuszczaną w innych Kościołach, a także w religiach niechrześcijańskich czy prawdowstawach cywilnych, możliwość rozwodu.

W odniesieniu do formy zawierania małżeństw mieszanych, zasadniczo prawodawca wymaga zawierania ich in facie Ecclesiae, wobec ordynariusza miejsca lub proboszcza albo kapłana lub diakona

\footnotetext{
10 Por. J. CAstaño, Il sacramento del matrimonio, dz. cyt., s. 468; Z. GrocholewsKi, I matrimoni misti, w: AA.Vv., Matrimonio canonico fra tradizione e rinnovamento, Bologna 1991, s. 269.
} 
delegowanego przez jednego z nich oraz w obecności dwóch świadków (por. kan. 1108 KPK). Jedyny wyjątek dotyczy małżeństwa strony katolickiej z niekatolikiem obrządku wschodniego: idąc bowiem za wskazaniami soborowego dekretu Orientalium Ecclesiarum ${ }^{11}$ oraz dekretu Kongregacji Kościołów Wschodnich Crescens matrimoniorum $^{12}$, prawodawca katolicki postanawia, aby w tym przypadku forma kanoniczna obowiązywała jedynie do godziwości, do ważności zaś konieczny jest, ale i wystarczający, udział świętego szafarza, z zachowaniem innych wymogów prawa ${ }^{13}$. Co więcej, przewiduje także możliwość, aby w poszczególnych przypadkach, w których poważne trudności nie pozwalają zachować formy kanonicznej, ordynariusz miejsca strony katolickiej mógł dyspensować od obowiązku zachowania formy kanonicznej, z zachowaniem jednak - i to do ważności - jakiejś publicznej formy zawarcia.

Nie jest natomiast możliwe stosowanie innych religijnych obrzędów zawarcia małżeństwa przed lub po wyrażeniu zgody małżeńskiej w Kościele katolickim, ani tym bardziej nie jest możliwy taki obrzęd religijny zawarcia małżeństwa, w którym asystowałby kapłan katolicki i niekatolicki, stosując równocześnie własny obrzęd małżeństwa i pytając nupturientów o ich zgodę. Norma ta wydaje się oczywista, tym niemniej należy odnieść się w sposób stanowczy wobec pojawiających się często koncepcji tzw. ślubów ekumenicznych, o których możliwość pytają osoby pragnące w jakiś sposób pogodzić pragnienia i zobowiązania obu stron w małżeństwie mieszanym. Możliwy jest natomiast udział szafarza wspólnoty niekatolickiej w celebracji małżeństwa mieszanego, polegający na odczytaniu Pisma św.,

11 Concilium Vaticanum II, Decretum de Ecclesiis Orientalibus Catholicis Orientalium Ecclesiarum, 21 XI 1964, AAS 57 (1965), s. 82, n. 18; tekst polski w: Sobór Watykańśki II. Konstytucje - dekrety - deklaracje, Poznań 2002, s. 182-183.

12 Sacra Congregatio pro Ecclesia Orientali, Decretum de matrimoniis mixtis inter catholicos et orientales baptizatos acatholicos Crescens matrimoniorum, 22 II 1967, AAS 59 (1967), s. 166; tekst polski w: E. SzTAfrowski, Posoborowe Prawodawstwo Kościelne, z. 2, Warszawa 1969, s. 59-60.

13 Na ten temat zob. U. NowickA, Kanoniczna forma zawarcia matżeństwa z prawosławnym wg KPK i KKKW, Prawo Kanoniczne 52 (2009) n. 3-4, s. 247-262. 
wypowiedzeniu słów krótkiej zachęty i pobłogosławieniu związku, jak również podobny udział kapłana katolickiego - za uprzednią zgodą ordynariusza miejsca - w obrzędzie zgodnego z prawem zawierania małżeństwa poza Kościołem katolickim ${ }^{14}$.

\section{Małżeństwa mieszane w ujęciu Kościoła prawosławnego}

Arcybiskup Sawa Hrycuniak pisze, że w ujęciu prawosławnym pojęcia „małżeństwo mieszane” używa się w podwójnym znaczeniu. Najpierw, w szerokim znaczeniu tego słowa, oznacza ono małżeństwo zawierane pomiędzy osobami należącymi do dwóch różnych wyznań, bez względu na to, czy są to wyznania chrześcijańskie, czy religie niechrześcijańskie. Natomiast w węższym znaczeniu jest to małżeństwo, które wierzący prawosławny zawiera z przedstawicielem drugiego wyznania chrześcijańskiego ${ }^{15}$. Stanowisko Kościołów prawosławnych wobec takich małżeństw jest jednoznaczne i mimo nieco różnej czasem praktyki, oparte na silnym fundamencie jedności wiary, dotyczącej samej istoty tego, co sprawia małżeństwo prawdziwie chrześcijańskie ${ }^{16}$. W tym stanowisku prawosławie odwołuje się przede wszystkim do starożytnych kanonów (zwłaszcza zaś do kan. 72 synodu trullańskiego ${ }^{17}$ ) oraz do faktu, że od chwili, gdy chrześcijaństwo stało się oficjalną religią Imperium Rzymskiego, zawieranie małżeństw z poganami było zabronione, a endogamia religijna stała

\footnotetext{
14 Papieska Rada ds. Popierania Jedności Chrześcijan, Dyrektorium w sprawie realizacji zasad i norm dotyczących ekumenizmu, 25 III 1993, n. 157-158.

15 Por. S. Hrycuniak, Prawosławne pojmowanie małżeństwa, Białystok 1994, s. 97.

16 Por. J. Meyendorf, Małżeństwo w prawosławiu. Liturgia, teologia, życie, Lublin 1995, s. 60.

17 Dyspozycja kan. 72 nie tylko zakazuje zawierania małżeństw z niechrześcijanami, ale również nakłada określone sankcje na tych, którzy nie zachowują zasad Kościoła: «Non licere virum orthodoxum cum muliere haeretica coniungi, neque vero orthodoxam cum viro haeretico copulari, sed et si quid eiusmodi ab ullo ex omnibus factum apparuerit, irritas nuptias existimare et nefarium coniugium dissolvi. Neque enim ea quae non sunt miscenda misceri, nec ovem cum lupo, nec peccatorum sortem cum Christi parte coniungi oportet»- w: J. D. MANsI, Sacrorum Conciliorum Nova Amplissima Collectio, vol. IX, Florentiae 1763, col. 975.
} 
się normalną praktyką Kościoła niepodzielonego w pierwszym tysiącleciu. Kościoły prawosławne wierne są tradycji, zwłaszcza w tym, co dotyczy stanowczego sprzeciwu wobec małżeństw z nieochrzczonymi. Analizując tę kwestię wybitny teolog prawosławny John Meyendorff pyta: „czy wszystkie ludzkie pokrewieństwa mogą być przemienione i przeobrażone w rzeczywistość Królestwa Bożego, jeśli nie jest wspólnym doświadczeniem to, czym Królestwo jest, jeśli nie wyznaje się wspólnie tej samej wiary? Czy jest możliwe stanie się „jednym ciałem” w Chrystusie bez wspólnego uczestnictwa w Jego eucharystycznym Ciele i Krwi? Czy dwoje ludzi może mieć udział w misterium małżeństwa - misterium, które jest nieodłączne od Chrystusa i Kościoła - bez wspólnego udziału w misterium Boskiej Liturgii?" 18 I następnie tłumaczy: „powinno być uznane za oczywiste, że kapłan prawosławny nigdy nie może błogosławić małżeństw pomiędzy prawosławnymi i niechrześcijanami. Czymś całkowicie niewłaściwym byłoby przyzywanie imienia Jezusa Chrystusa podczas nabożeństwa zaślubin nad osobą, która nie uznaje Go za swego Pana. Takie wezwanie mogłoby być lekceważące, nie tylko wobec Pana, ale również wobec tej osoby i jej przekonań (lub braku przekonań)"19. Podobne sformułowania znajdujemy także u Sawy Hrycuniaka, który w słowach bardzo mocnych stwierdza: „Kapłan prawosławny nie ma prawa udzielić sakramentu małżeństwa wyznawcy prawosławnemu $\mathrm{z}$ nieochrzczonym. Trudno wprowadzać do obrzędu sakramentu imię tego, kto nie uznaje Zbawiciela. Byłaby to profanacja"20.

Natomiast małżeństwa $\mathrm{z}$ osobami należącymi do innego wyznania chrześcijańskiego, choć w teorii również zabronione, w praktyce jednak mają miejsce. Nie uznaje się ich za doskonałe, ale także nie odrzuca całkowicie, a z uwagi na ducha „ekonomii” pasterskiej Kościoła, nawet się je błogosławi ${ }^{21}$.

\footnotetext{
18 J. Meyendorfa, Małżeństwo w prawosławiu..., dz. cyt., s. 60-61.

19 Tamże, s. 62.

20 S. Hrycuniak, Prawosławne pojmowanie małżeństwa, dz. cyt., s. 101.

21 Por. tamże, s. 101-102.
} 
Specyfiką prawosławia natomiast jest fakt, że nie wszystko i nie zawsze ujmowane jest w normy prawne, na wzór katolicki, z których możliwe byłoby odczytanie współczesnych koncepcji i wymogów ${ }^{22}$. Tym niemniej, jak pisze Joseph Prader, dzisiaj prawosławie, w ujęciu najbardziej ogólnym, dopuszcza małżeństwa z katolikami i protestantami kat'oikonomiam pod dwoma warunkami: po pierwsze, że takie małżeństwo zostanie zawarte po uprzednim zezwoleniu biskupa i wobec kapłana prawosławnego, i po drugie, że oboje małżonkowie przyrzekną, że ich dzieci będą ochrzczone i wychowane w religii prawosławnej $^{23}$.

Tym niemniej istotne znaczenie kwestii małżeństw mieszanych dla Kościołów prawosławnych spowodowało, iż została ona włączona w katalog tematów przyszłego Soboru Ogólnoprawosławnego. Pierwsza szczegółowa dyskusja na ten temat miała miejsce w 1971 r. w ramach Międzyprawosławnej Komisji Przygotowawczej, która na podstawie raportów i sugestii przekazanych przez lokalne Kościoły prawosławne wypracowała wstępny schemat dokumentu zatytułowany Przeszkody małżeńskie. Szczególną rolę odegrało tutaj stanowisko Polskiego Autokefalicznego Kościoła Prawosławnego, który - w duchu autentycznego ekumenizmu oraz w oparciu o doświadczenie

\footnotetext{
${ }^{22}$ W dokumentach niektórych tylko Kościołów prawosławnych odnaleźć można bezpośrednie wskazania w tym względzie. Np. w dokumencie Społeczna doktryna Rosyjskiej Cerkwi Prawosławnej z 2000 r., X.2 czytamy, iż wspólna wiara małżonków jest podstawowym warunkiem zawarcia małżeństwa, gdyż tylko rodzina wyznająca jedną wiarę może stać się prawdziwym „Kościołem domowym”. Jednak, w oparciu o duszpasterską zasadę ekonomii, rosyjski Kościół prawosławny zezwala na małżeństwa z tymi, którzy wyznają wiarę w Boga w Trójcy jedynego, pod warunkiem, że małżeństwo to zostanie pobłogosławione w Kościele prawosławnym, a dzieci wychowane w wierze prawosławnej. W Przesłaniu do narodu bułgarskiego Stefana I z 1945 r. podkreślano, iż zawarcie małżeństwa z niechrześcijanami jest zakazane; natomiast w małżeństwach mieszanych z chrześcijanami nieprawosławnymi, strona nieprawosławna musi złożyć specjalną deklarację, że dzieci będą wychowane w duchu wiary prawosławnej. Na mocy ustawy 2320/1982 Kościoła greckiego małżeństwo $\mathrm{z}$ innowiercami jest niemożliwe, dopuszcza się natomiast, w oparciu o zasadę oikonomii i pod pewnymi warunkami, związki z innymi chrześcijanami.

23 Por. J. Prader, Il matrimonio in Oriente e Occidente, Roma 1992, s. 141.
} 
lokalnych relacji międzywyznaniowych - oprócz zdecydowanej opinii na temat ważności małżeństw zawieranych przez prawosławnych ze wszystkimi, którzy przyjęli sakrament chrztu, zaproponował także poddanie pod dyskusję możliwości udzielenia małżeństwa w przypadku, gdy jedna ze stron jest niewierząca ${ }^{24}$. Podobne było stanowisko przedstawicieli Patriarchatu Moskiewskiego, zdaniem których aktualne warunki, w jakich Kościół istnieje na ziemi zmuszają do powrotu do kościelnej praktyki pierwszych trzech wieków, kiedy to Kościół, zgodnie ze słowami św. Pawła (1 Kor 7, 12-14, 16) akceptował takie małżeństwa ${ }^{25}$. Dlatego Kościół jest w stanie zaakceptować małżeństwa prawosławnych z innymi chrześcijanami, pobłogosławione $\mathrm{w}$ Cerkwi wraz $\mathrm{z}$ rytem koronacji, byleby strona nieprawosławna uznawała znaczenie benedykcji udzielanej przez Kościół prawosławny. Co więcej, biorąc pod uwagę, że Kościół katolicki uznaje ważność małżeństw zawieranych z prawosławnymi, także i Kościół prawosławny jest gotowy uznać takie małżeństwa, zawarte w wyjątkowych okolicznościach, i po uzyskaniu zgody biskupa prawosławnego, wobec kapłana katolickiego ${ }^{26}$.

Ten wstępny schemat przedstawiony został na forum I Ogólnoprawosławnej Konferencji Przedsoborowej w 1976 r., a następnie, uzupełniony, uzyskał ostateczną aprobatę w 1982 r. Treść tego dokumentu z pewnością odbiega od wielowiekowej praktyki kanonicznej Kościoła. Mimo to, ze zrozumiałych względów, kwestia ewentualnych małżeństw z niechrześcijanami bądź niewierzącymi została potraktowana surowiej niż małżeństwa mieszane sensu stricto, choć i tutaj stanowisko prawosławne uległo jakby pewnemu złagodzeniu. Konferencja Przedsoborowa wysunęła bowiem następującą propozycję dla przyszłego Soboru: „Małżeństwo między prawosławnymi i nieprawosławnymi stanowi przeszkodę według reguł kanonicznych

\footnotetext{
24 Por. T. KAŁUŻNy, Nowy Sobór Ogólnoprawosławny. Natura, historia przygotowań, tematyka, Kraków 2008, s. 305; J. Prader, Il matrimonio in Oriente e Occidente, dz. cyt., s. 142.

25 Por. tamże.

26 Tamże, s. 141-142.
} 
(akrybii). Jednakże może być ono zawierane ze względu na wyrozumiałość i miłość do człowieka, pod warunkiem, że dzieci zrodzone z tego małżeństwa zostaną ochrzczone i wychowane w Kościele prawosławnym. Lokalne Kościoły prawosławne mogą podejmować decyzje odnośnie do zastosowania w konkretnych przypadkach ekonomii zależnie od swoich potrzeb duszpasterskich”, dodając jednocześnie, iż „Małżeństwo pomiędzy prawosławnymi i niechrześcijanami lub niewierzącymi jest absolutnie zabronione według reguł kanonicznych (akrybii). Lokalne Kościoły prawosławne mogą jednak zadecydować w wypadku takiego małżeństwa, co do zastosowania ekonomii duszpasterskiej dla strony prawosławnej, biorąc pod uwagę szczególne potrzeby duszpasterskie"27.

Mimo tak zliberalizowanych dążeń prawosławia nie należy jednak zapominać, że jak dotychczas idea Soboru nadal nie została zrealizowana. Wedle ostatnich źródeł, ma on zostać zwołany na drugi dzień Pięćdziesiątnicy $2016 \mathrm{r}^{28}$. Tym niemniej na dzień dzisiejszy propozycje Konferencji Przedsoborowej pozostają nadal w kategoriach jedynie propozycji, nie mają zaś mocy obowiązującej. To zaś oznacza, że wedle aktualnej koncepcji prawosławnej małżeństwo z osobą nieochrzczoną jest niemożliwe, zaś z wiernymi nieprawosławnymi - możliwe ze względu na ekonomię kościelną i jedynie pod pewnymi warunkami.

\section{Małżeństwa mieszane w ujęciu Kościoła ewangelicko-augsburskiego w RP}

Zasady służby i postępowań w Kościele ewangelicko-augsburskim w RP określa „Pragmatyka Służbowa” tegoż Kościoła, zatwierdzona na 4 Sesji Synodu X Kadencji ze zmianami dokonanymi do 4 Sesji

\footnotetext{
27 Treść tego dokumentu, przetłumaczony z języka francuskiego na język polski, zamieszcza w swojej rozprawie habilitacyjnej T. Kałużny, Nowy Sobór Ogólnoprawosławny..., dz. cyt., s. 307-308.

28 Informacja zaczerpnięta z: http://ekai.pl/wydarzenia/ekumenizm/x76091/sobor-wszechprawoslawny-w-roku/; http://wiadomosci.monasterujkowice.pl/?p=15981 (dostęp: 30 kwietnia 2015 r.).
} 
Synodu XIII Kadencji, datowana na dzień 27 października 2012 r. ${ }^{29}$. Jest to dokument zawierający szereg przepisów odnoszących się także do życia małżeńskiego i rodzinnego, w tym również do kwestii małżeństw o różnej przynależności wyznaniowej, religijnej lub światopoglądowej (\$130-144).

Już z pierwszych słów tego działu wynika, że Kościół ewangelicko-augsburski świadomy jest trudności, jakie niosą za sobą małżeństwa mieszane, nazywając je „małżeństwami niosącymi brzemię różnicy wyznań, religii lub światopoglądu”. Zezwala na nie, jednak powierza je szczególnej trosce Kościoła oraz wzmożonej odpowiedzialności małżonka ewangelickiego ${ }^{30}$. Jedyny wyjątek w tym kontekście stanowią małżeństwa duchownych, którym zabrania się, pod rygorem skreślenia z listy duchownych Kościoła, zawierania małżeństwa z osobą należącą do innego Kościoła, chyba że chodzi o wiernych Kościołów pozostających z Kościołem ewangelicko-augsburskim w RP we wspólnocie ołtarza i ambony ${ }^{31}$, tzn. Kościoła ewangelicko-metodystycznego i ewangelicko-reformowanego.

W analizowanych przepisach nie ma wprawdzie bezpośrednich wskazań co do konieczności składania przez stronę ewngelicką przyrzeczeń czy oświadczeń, których wymaga prawodawca katolicki. Tym niemniej nie można nie zauważyć, iż również Kościół ewangelicko-augsburski nakłada na swoich wiernych obowiązki, szczególnie istotne w kontekście zawierania małżeństw mieszanych. Wydaje się jednak, iż ustawodawstwo ewangelickie ukierunkowane jest ku odpowiedzialności podejmowanej indywidualnie przez wiernych oraz rozstrzyganej w ich sumieniu, nie wymagając przy tym formalnego, wyrażonego na zewnątrz w przepisanej prawem formie zobowiązania. W $\$ 133$ Pragmatyki Służbowej czytamy bowiem, że „duchowni są zobowiązani pouczyć wiernych, że przed podjęciem decyzji zawarcia

\footnotetext{
29 Pragmatyka służbowa Kościoła Ewangelicko-Augsburskiego w Rzeczpospolitej Polskiej, http://bik.luteranie.pl/files/Prawo/20-12-2013Pragmatyka.pdf (data dostępu: 2 maja 2015 r.).

30 Por. tamże, $\$ 130$.

31 Por. tamże, $₫ 156$.
} 
takiego małżeństwa winni się poważnie zastanowić, czy będą w mocy sprostać swojemu w nim zadaniu i czy nie stanie im na przeszkodzie postawa ich własnej rodziny oraz własna ich słabość", a następnie, że są oni „zobowiązani nie tylko do zachowania wierności Bogu i Kościołowi w osobistym życiu, ale też przy wszelkim poszanowaniu współmałżonka, do nadania domowi ewangelickiego charakteru, a zwłaszcza do wychowania dzieci w Kościele ewangelicko-augsburskim”. Aktualność tych zobowiązań podkreśla się także w sytuacji, w której możliwe jest uzyskanie dyspensy biskupa diecezjalnego na zawarcie małżeństwa poza Kościołem ewangelicko-augsburskim ${ }^{32}$, o czym będzie mowa poniżej.

Obowiązki wobec własnej wiary, a także wobec potomstwa stanowią zatem - jak się wydaje - warunek konieczny dla możliwości zawarcia małżeństwa przez ewangelika $\mathrm{z}$ wyznawcą innego wyznania lub religii. Tym niemniej należy zwrócić uwagę, że w odniesieniu do potomstwa mowa jest jedynie o wychowaniu, nie zaś o chrzcie w Kościele ewangelicko-augsburskim. Czy oznacza to, że samo miejsce chrztu pozostaje dla prawodawcy ewangelickiego obojętne, zaś istotne znaczenie posiada jedynie wychowanie potomstwa? Wydaje się, że nie. Słuszna jest w tym przypadku interpretacja dokonana przez Gintera Dzierżona, wedle którego skoro prawodawca mówi o wychowaniu, to implicite zakłada ochrzczenie dziecka w Kościele ewangelicko-augsburskim. Znajduje to - zdaniem Autora - umocowanie w normatywnych zwrotach odnoszących się do konieczności nadania domowi ewangelickiego charakteru, a tym bardziej w aplikacji $₫ 111$ Pragmatyki Służbowej, w którym ustawodawca ewangelicki uwydatnił ścisły związek zachodzący między chrztem a wychowaniem potomstwa w duchu ewangelickim ${ }^{33}$ : „szczególnym obowiązkiem rodziców, wynikającym z nakazu misyjnego Pana

\footnotetext{
32 Por. tamże, $\$ 136$.

33 Por. G. Dzierżon, Realizacja warunków dotyczących nupturientów w przypadku zawierania małżeństwa katolika $z$ wiernym Kościoła Ewangelicko-Augsburskiego $w$ Polsce, w: U. Nowicka (red.), Kanoniczno-liturgiczne aspekty zawierania matżeństw mieszanych i im podobnych, Warszawa 2014, s. 93-94.
} 
Jezusa Chrystusa, jest wprowadzenie dzieci we wspólnotę Kościoła przez Chrzest św., nauczanie Słowa Bożego, modlitwę i religijne wychowanie".

Ustawodawstwo ewangelickie wymaga następnie, aby w ramach przygotowania do małżeństwa, nupturientom została przedstawiona problematyka małżeństw mieszanych, w zakresie trudności, jakie mogą się pojawić w ich funkcjonowaniu, a także różnic wyznaniowych, religijnych i światopoglądowych. Wydaje się, iż w ramach tych ostatnich istotne znaczenie, w aspekcie małżeństw zawieranych z katolikami, będą miały kwestie dotyczące rozumienia nierozerwalności małżeństwa. Wprawdzie w $\$ 107$ n. 2 Pragmatyki Służbowej zapisano, iż „,istotnymi przymiotami małżeństwa są: jedność i nierozerwalność, które w małżeństwie chrześcijańskim nabierają szczególnej mocy $\mathrm{z}$ racji Bożego ustanowienia i autorytetu", tym niemniej jednocześnie uznaje się możliwość rozwodu, jako „tolerowaną konieczność wynikającą z grzesznej natury człowieka"34.

Małżeństwo, w którym tylko jedna strona jest ewangelicka, powinno być zawierane w jej Kościele parafialnym i według porządku liturgicznego Kościoła ewangelicko-augsburskiego oraz wobec duchownego tegoż Kościoła ${ }^{35}$. Ze względu na wspomnianą wyżej wspólnotę ołtarza i ambony z Kościołem ewangelicko-reformowanym i Ewangelicko-Metodystycznym, prawo przewiduje możliwość, aby - jeśli małżeństwo ma być zawierane z wiernymi tych Kościołów asystował przy nich tamtejszy duchowny ${ }^{36}$. Natomiast w przypadku pozostałych małżeństw, zróżnicowanych wyznaniowo, ale nie religijnie, możliwa jest jedynie obecność duchownego reprezentującego Kościół drugiej strony, której to rodzaj i zakres ma być każdorazowo uzgadniany z proboszczem miejsca i biskupem diecezjalnym ${ }^{37}$.

\footnotetext{
34 Stanowisko Kościoła Ewangelicko-Augsburskiego w RP wobec małżeństwa, http://www.luteranie.pl/materialy/rozne_pisma/stanowisko_kosciola_ewangelicko_augsburskiego_w_rp_wobec_malzenstwa,358.html (data dostępu: 2 maja 2015 r.).

35 Por. Pragmatyka Służbowa, \$134-135.

36 Por. tamże, $\$ 135$.

37 Por. tamże, $\$ 143$.
} 
Podobnie możliwa jest obecność duchownego ewangelickiego podczas zawierania małżeństwa w innym Kościele chrześcijańskim ${ }^{38}$. Zakłada to więc, iż ustawodawstwo ewangelickie przewiduje możliwość zawierania małżeństw przez swoich wiernych poza Kościołem ewangelicko-augsburskim. I rzeczywiście, możliwość taka istnieje, choć jest uwarunkowana istnieniem poważnych trudności nie pozwalających zachować zwyczajnych przepisów prawa w zakresie zawierania małżeństw oraz uzyskaniem dyspensy biskupa diecezjalnego, który decyzję podejmuje po konsultacji z właściwym proboszczem ${ }^{39}$. Zabrania się natomiast, na wzór katolicki, „przed lub po zawarciu małżeństwa w Kościele ewangelicko-augsburskim, stosować inne religijne zawarcie tegoż małżeństwa w celu wyrażenia lub odnowienia zgody małżeńskiej” "40, a także stosować „taki obrzęd, w którym asystujący duchowny ewangelicki i duchowny nieewangelicki, stosując równocześnie własny obrzęd czy formułę, pytają o wyrażenie zgody małżonków (stron)" ${ }^{41}$.

\section{Wnioski}

17 października 2014 r., w ramach XIII Ekumenicznego Święta Biblii w Poznaniu, przedstawiciele trzech wyznań chrześcijańskich: rzymsko-katolickiego, prawosławnego i ewangelicko-augsburskiego wzięli udział w panelu dyskusyjnym na temat „Małżeństwo mieszane - zagrożenie czy błogosławieństwo?”"2. Z treści ich wypowiedzi wnioskować można o świadomości trudności, jakie mogą pojawić się w tego typu małżeństwach, jednak wydaje się, iż równie widoczny $\mathrm{w}$ ich wypowiedziach był aspekt pozytywny, oparty na potrzebie akcentowania tego, co łączy, a nie co dzieli małżonków. To prawda, tym

\footnotetext{
38 Por. tamże.

39 Por. tamże, $\$ 136$.

40 Tamże, $\$ 142$.

41 Tamże, $\$ 144$.

42 Poznań: debata o matżeństwach mieszanych podczas XIII Ekumenicznego Święta Biblii, http://ekai.pl/diecezje/x82986/poznan-debata-o-malzenstwach-mieszanych-podczas-xiii-ekumenicznego-swieta-biblii/ (data dostępu: 2 maja 2015 r.).
} 
niemniej nie można pominąć faktu, iż każdy z omówionych powyżej Kościołów - słusznie i w ramach poczucia własnej tożsamości - stawia małżonkom wymagania, których zachowanie jest $\mathrm{z}$ jednej strony konieczne, z drugiej jednak już na starcie suponuje problemy nie zawsze możliwe do pokonania. O ile obowiązek zachowania własnej wiary może być realizowany (choć nie bez szkody dla doskonałej jedności rodziny), o tyle znacznie trudniejsze jest wymaganie dotyczące wychowania potomstwa w wierze przez siebie wyznawanej. Każdy Kościół chce i wymaga od swojego wiernego takiego zobowiązania, co pozwala z góry zakładać, że któryś z małżonków go nie wypełni. Albo będzie to wynikiem ustępstw ze strony jednego z małżonków (których przecież nie wolno mu czynić) albo ceną za próbę realizacji własnych zobowiązań będzie konflikt w rodzinie. Nie jest to perspektywa dobra, przez co tym bardziej uwidacznia się pilna potrzeba poważnej refleksji teologicznej i prawnej w tym zakresie.

\section{Mixed marriages in the concept of the Catholic Church, the Orthodox Church and the Evangelical Church of the Augsburg Confession in Poland}

\section{Summary}

In times of multiculturalism and religious pluralism issue of mixed marriages it is very timely. It is an object of interest of all faiths and religions. The author of the present article takes the issue of mixed marriages from the point of view of three Christian faiths: Roman Catholic Church, the Orthodox Church and the Evangelical Church of the Augsburg Confession in Poland. Each of these churches makes his faithful requirements that are necessary to be able to to marry with a person of another faith or religion. Unfortunately, the similarity these norms can lead to difficulties in marriages of different religious or church affiliation. 